\title{
CONTENTS VOLUME 10 (1992)
}

Editorial 1

Life values of library and information studies students and faculty

J. KIRK and B. POSTON-ANDERSON

Undergraduate and graduate courses in Information Resources Management: Educational and managerial judgement about appropriate course content

J. LARIBEE

Online searching and CD-ROM in British schools

M. BUTTERWORTH

Professional socialisation of students of library and information science in a fieldwork programme M. NASSIMBENI

Book Reviews

News

Editorial

Dimensions of competence: interpersonal skills development within the LIS curriculum

P. LEVY

Improving education for information at the University of Papua New Guinea - the search for resources

J. EVANS

Quality assessment of library and information science school facilities

W. BRACE

The use of BookshelF in teaching students of Information and Library Management

J.E. ROWLEY and S. FISHER

Book Reviews

News

Editorial

Education and training for librarianship and information work: Annual bibliography, 1991 A.J. CLARK

Patents information in the library/information studies curriculum

I. McKEVITT

Book Reviews

Foreword

J. BURCHELL

Editorial

S. KEENAN 
The silent consumer: foreign students in U.K.'s library and information science programmes. Theme paper

J. OJIAMBO

Different perspectives - different purposes: some impressions relating to the education of overseas students

I. JOHNSON

Opening address (videotape presentation)

J. OJIAMBO

Brain Train - professional education and training requirements in developing countries S. KEENAN

View from the rock face - survey of overseas students currently studying in the U.K. S. KEENAN

Links, exchanges and sharing

J. SHEARER

The role of the British Council

G. BATE

Working group discussions

Concluding remarks

R. BOWDEN

List of Conference participants

Book Reviews

Master Index Volume 1-10 